\title{
Disappearance of Cyclin A Correlates with Permanent Withdrawal of Cardiomyocytes from the Cell Cycle in Human and Rat Hearts
}

\author{
Masao Yoshizumi, ${ }^{\star \delta}$ Wen-Sen Lee, ${ }^{\star 5}$ Chung-Ming Hsieh,* Jer-Chia Tsai,* Jian Li,* Mark A. Perrella, ${ }^{\star \$ 1}$ \\ Cam Patterson,* Wilson O. Endege,* Robert Schlegel," and Mu-En Lee*\$1 \\ *Cardiovascular Biology Laboratory and ${ }^{\ddagger}$ Department of Molecular and Cellular Toxicology, Harvard School of Public Health; \\ ${ }^{\S}$ Department of Medicine, Harvard Medical School; and "Pulmonary and 'Cardiovascular Divisions, Brigham and Women's Hospital, \\ Boston, Massachusetts 02115
}

\begin{abstract}
The regulated expression of cyclins controls the cell cycle. Because cardiomyocytes in adult mammals withdraw permanently from the cell cycle and thus cannot regenerate after injury, we examined cyclin espression during development by comparing cyclin A-E mRNA levels in fetal and adult human hearts. Cyclin B mRNA was detectable in adult hearts, although at a level markedly lower than that in fetal hearts. Levels of cyclin C, D1, D2, D3, and E mRNA were essentially identical in the two groups. In contrast, cyclin A mRNA was undetectable in adult hearts whereas cyclin A mRNA and protein were readily detectable in fetal hearts and cardiomyocytes, respectively. We then measured cyclin A mRNA and protein levels in rat hearts at four stages of development (fetal and 2, 14, and 28 d). Cyclin A mRNA and protein levels decreased quickly after birth (to $37 \%$ at day 2) and became undetectable within $14 \mathrm{~d}$, an observation consistent with reports that cardiomyocytes stop replicating in rats by the second to third postnatal week. This disappearance of cyclin $A$ gene expression in human and rat hearts at the time cardiomyocytes become terminally differentiated suggests that cyclin A downregulation is important in the permanent withdrawal of cardiomyocytes from the cell cycle. (J. Clin. Invest. 1995. 95:2275-2280.) Key words: cardiomyocytes $\cdot$ cell cycle $\cdot$ cyclins $\cdot$ gene regulation $\cdot$ heart
\end{abstract}

\section{Introduction}

In mammalian hearts, cardiomyocytes proliferate throughout fetal development and into the early neonatal period (1-8). During the early postnatal period cardiomyocyte division ceases and DNA replication declines quickly (5-8). Because cardiomyocytes have withdrawn permanently from the cell cycle by the time mammals reach adulthood, their cardiac tissue cannot regenerate after injury such as myocardial infarction. A thorough understanding of the mechanisms that regulate this withdrawal could suggest strategies for regenerating damaged cardiac tissue.

Address correspondence to Dr. Mu-En Lee, Cardiovascular Biology Laboratory, Harvard School of Public Health, 677 Huntington Avenue, Boston, MA 02115. Phone: 617-432-4994; FAX: 617-432-0031.

Received for publication 9 August 1994 and in revised form 13 December 1994.

J. Clin. Invest.

(C) The American Society for Clinical Investigation, Inc.

0021-9738/95/05/2275/06 \$2.00

Volume 95, May 1995, 2275-2280
The progress of the cell cycle is regulated by the expression of cyclins and the activation of their associated cyclin-dependent kinases (Cdks) ${ }^{1}(9-14)$. Cyclin $A$ is a key molecule in the $S$ and $G 2 / M$ phases (15-17), cyclin B is important in the G2/ $M$ phase (18), and cyclin C, the three D-type cyclins (D1, D2, and D3), and cyclin E have been implicated in the G1 phase $(9,19-22)$. In both normal and cancer cells $(10,23)$, the cell cycle is regulated by these cyclins and their attendant Cdks. Recently, several negative regulators of the Cdks have been identified (23-25); these proteins, termed Cdk inhibitory proteins, bind to the Cdk-cyclin complex and inhibit its activity (26-31). The Cdk2-cyclin E complex can be inhibited by p21 and p27, the Cdk4-cyclin D complex by p21 and p16, and the Cdk2-cyclin A complex by p21 only (25).

To determine whether cyclin expression is important in the withdrawal of cardiomyocytes from the cell cycle, we studied cyclin mRNA levels in human fetal and adult hearts. We found no difference between fetal and adult hearts in the mRNA levels of cyclins $\mathrm{C}-\mathrm{E}$. In contrast, cyclin A mRNA was undetectable in adult hearts but readily detectable in fetal hearts, as was cyclin A protein in fetal cardiomyocytes. In rats, cardiac cyclin A mRNA and protein levels quickly decreased after birth (to $37 \%$ at day 2) and were undetectable after $14 \mathrm{~d}$, in keeping with the observation that cardiomyocytes stop replicating by the second to third postnatal week. Downregulation of cyclin A thus appears to have an important role in the withdrawal of cardiomyocytes from the cell cycle.

\section{Methods}

Cloning of human and rat cyclin cDNAs. Human cyclin A, B, C, D1, D2, D3, and E cDNA fragments were amplified from the mRNA of human umbilical vein endothelial cells or HeLa cells by the reverse transcription polymerase chain reaction as described $(32,33)$. The primers were based on published sequences:

cyclin A, forward 5'-CGTGGACTGGTTAGTTGA-3' and reverse 5'-ATGGCAAATACTTGAGGT-3' (34);

cyclin B, forward 5'-CAGGCTTTCTCTGATGTA-3' and reverse 5'-TAGCCAGGTGCTGCATAA-3' (18);

cyclin $\mathrm{C}$, forward $5^{\prime}$-TCCATGGCAGGGAACTTT-3' and reverse 5'-AGATTGGCTGTAGCTAGA-3' (21); cyclins D1 and D2, forward 5'-GARGTNTGYGARGARCA-3' and reverse 5'-TCDATYTGYTCYTGRCA-3' (20); cyclin D3, forward 5'-GCTTACTGGATGCTGGAGGTATGTG-3' and reverse 5'-ACATCTGTAGGAGTGCTGGTCTGG-3' (20); and cyclin E, forward 5'-TTCTCGGCTCGCTCCAGGAA-3' and reverse 5' -TGGAGGATAGATTTCCTC-3' (22).

We obtained a rat cyclin A cDNA fragment from the mRNA of rat

1. Abbreviations used in this paper: Cdk, cyclin-dependent kinase; PCNA, proliferating cell nuclear antigen. 


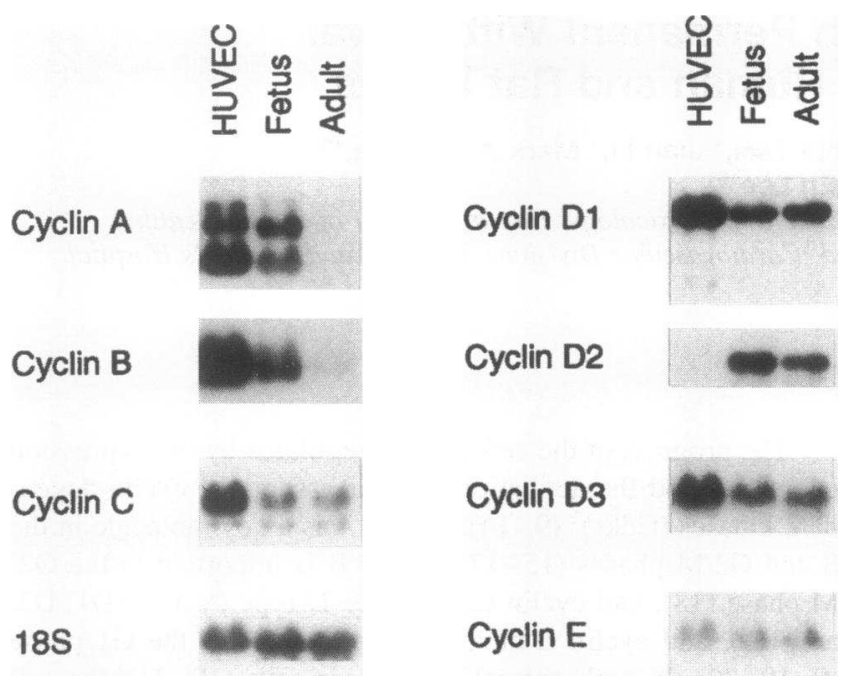

Figure 1. Cyclin mRNA levels in human fetal and adult hearts. Total RNA was extracted from cultured human umbilical vein endothelial cells (HUVEC) or human hearts (Fetus and Adult). Northern blot analyses were performed with $20 \mu \mathrm{g}$ of total RNA per lane. After electrophoresis RNA was transferred to nitrocellulose filters, which were hybridized to ${ }^{32} \mathrm{P}$-labeled human cyclin probes. Filters were also hybridized to $18 \mathrm{~S}$ oligonucleotide probes to verify equal loading of RNA in each lane.

aortic smooth muscle cells by the reverse transcription polymerase chain reaction using the same primers for human cyclin A. All PCR fragments were subcloned and their authenticity was confirmed by dideoxy chain termination sequencing $(33,35,36)$.

RNA blotting. Total RNA from the ventricles of two 21-wk-old human fetuses was prepared by guanidinium isothiocyanate extraction and centrifuged through cesium chloride $(32,33)$. (The use of this tissue was approved by the Human Research Committee of the Brigham and Women's Hospital, Boston.) Total RNA from human adult hearts was purchased from Clontech (Palo Alto, CA). Total RNA from rat (Sprague-Dawley) ventricular tissue was obtained at four stages of development: fetal (18-19 d gestation), 2, 14, and $28 \mathrm{~d}$. RNA was fractionated on $1.3 \%$ formaldehyde-agarose gels and transferred to nitrocellulose filters, which were hybridized with randomly primed ${ }^{32} \mathrm{P}$-labeled cyclin cDNA probes as described $(32,33)$. The hybridized filters were washed in $30 \mathrm{mM} \mathrm{NaCl}, 3 \mathrm{mM}$ sodium citrate, and $0.1 \%$ sodium dodecyl sulfate at $55^{\circ} \mathrm{C}$ and autoradiographed on Kodak XAR film at $-80^{\circ} \mathrm{C}$ for $12-$ $48 \mathrm{~h}$ or stored on phosphor screens for $6-12 \mathrm{~h}$. To correct for differences in RNA loading, we washed the filters at $80^{\circ} \mathrm{C}$ in $50 \%$ formamide solution to remove the cyclin probes and then rehybridized them with the radiolabeled $18 \mathrm{~S}$ oligonucleotide $(32,33)$. Filters were scanned and radioactivity was measured on a PhosphorImager apparatus running the ImageQuant software (Molecular Dynamics, Inc., Sunnyvale, CA).

Western blotting. Cardiac ventricles obtained from Sprague-Dawley rats at various stages of development were homogenized and boiled in equal volumes of $2 \times$ sample loading buffer $(36,37)$. Homogenized samples containing $100 \mu \mathrm{g}$ of protein were run on $10 \%$ sodium dodecylsulfate polyacrylamide gels $(36,37)$. Proteins were electroblotted onto a polyvinylidene difluoride membrane (Immobilon; Millipore Corp., Bedford, MA) in a semi-dry blotting apparatus (Hoefer Scientific Instruments, San Francisco, CA). Filters were incubated with a rabbit polyclonal anti-human cyclin A antibody $(38,39)$, which was diluted 1:5000 after having been blocked with $3 \%$ bovine serum albumin. The filters were then washed and incubated with a 1:5000 dilution of donkey anti-rabbit Ig horseradish peroxidase-conjugated antibody (Amersham Corporation, Arlington Heights, IL). Bound antibody was detected with the Renaissance Chemiluminescence System (DuPont NEN, Boston, MA).

Immunocytochemistry. Human fetal heart (20-wk-old) specimens in methyl Carnoy's fixative were processed for paraffin embedding in an automated system (Hypercenter XP, Shandon Scientific Ltd). Male rats ( 2 or $14 \mathrm{~d}$ old) were perfused with $4 \%$ paraformaldehyde, and the hearts were removed and embedded in paraffin or $\mathbf{O}$. C. T. (optimum cutting temperature) compound (Miles, Elkhart, IN). Both human and rat heart specimens were cut at a thickness of $5 \mu \mathrm{m}$. Immunocytochemical analysis of cyclin A and proliferating cell nuclear antigen (PCNA) was performed as described $(40,41)$. Briefly, the tissue was incubated with a rabbit polyclonal anti-human cyclin A antibody $(20 \mu \mathrm{g} / \mathrm{ml}$, UBI, Lake Placid, NY) or mouse monoclonal anti-PCNA antibody ( $3 \mu \mathrm{g} / \mathrm{ml}$, Oncogene Science, NY) for $1 \mathrm{~h}$ at room temperature and then overnight at $4^{\circ} \mathrm{C}$. Staining was visualized by an immunoperoxidase technique, with diaminobenzidine used as chromogen to yield a brown reaction product (40). The tissue was counter-stained with methyl green to visualize the nuclei.

For double-immunofluorescent staining, human fetal heart tissue sections were incubated with a mixture of primary antibodies - anti-human cyclin A $(40 \mu \mathrm{g} / \mathrm{ml})$ and anti-PCNA $(6 \mu \mathrm{g} / \mathrm{ml})$ or anti-human cyclin A (40 $\mu \mathrm{g} / \mathrm{ml})$ and anti-desmin (monoclonal, 1:20 dilution, Amersham, Buckinghamshire, England) - for $1 \mathrm{~h}$ at room temperature and overnight at $4^{\circ} \mathrm{C}$. After having been washed three times with $1 \times$ PBS, the tissue sections were incubated with a mixture of two secondary antibodies: fluorescein isothiocyanate-conjugated goat anti-rabbit IgG (1:20; Boehringer Mannheim, Indianapolis, IN) and rhodamine-conjugated goat anti-mouse IgG (1:20, Boehringer Mannheim). Cyclin A and PCNA or cyclin A and desmin were visualized in a cameraequipped, Nikon immunofluorescence microscope. Two photographs of the double-labeled sections were taken sequentially: first at the wavelength specific for fluorescein isothiocyanate fluorescence and then (without changing the slide) at the wavelength specific for rhodamine fluorescence. Cyclin A immunoreactivity stained yellow and PCNA or desmin immunoreactivity stained red.

\section{Results}

As a positive control, total RNA prepared from cycling human umbilical vein endothelial cells was hybridized with cyclin probes. We detected transcripts of cyclins A, B (B1), C, D1, $D 3$, and $E$ in total RNA prepared from human umbilical vein endothelial cells (Fig. 1), and the size of each transcript was as

Figure 2. Expression of cyclin A protein in human and rat cardiomyocytes. Cyclin A immunoreactivity was detected in heart tissue by singleimmunoperoxidase methods ( $A$ and $B$, human tissue; $E$ and $F$, rat tissue) and dual-immunofluorescent methods $(C$ and $D$, human tissue). Arrows denote nuclei stained positively with cyclin A or PCNA antibodies. $(A)$ Low magnification micrograph $(\times 230)$ showing the distribution of cyclin A (brown spots) in human fetal heart tissue. $(B)$ High magnification micrograph $(\times 700)$, corresponding to the area defined by the square in $A$, showing striated morphology and large nuclei of cardiomyocytes in human fetal heart tissue. Three cardiomyocyte nuclei positive for cyclin $A$ are visible. (C) Two cells from a human fetal heart stained with antibody to cyclin A (yellow, arrows). (D) Same two cyclin A-positive cells in $C$ stained with antibody to PCNA (red, arrows). (E) High magnification micrograph $(\times 700)$ of a 2-d-old rat heart section showing many nuclei stained with antibody to cyclin A. The arrow shows a representative nucleus positive for cyclin $A$. $(F)$ High magnification micrograph $(\times 700)$ of a 14-d-old rat heart section showing no cyclin A-positive nuclei. 

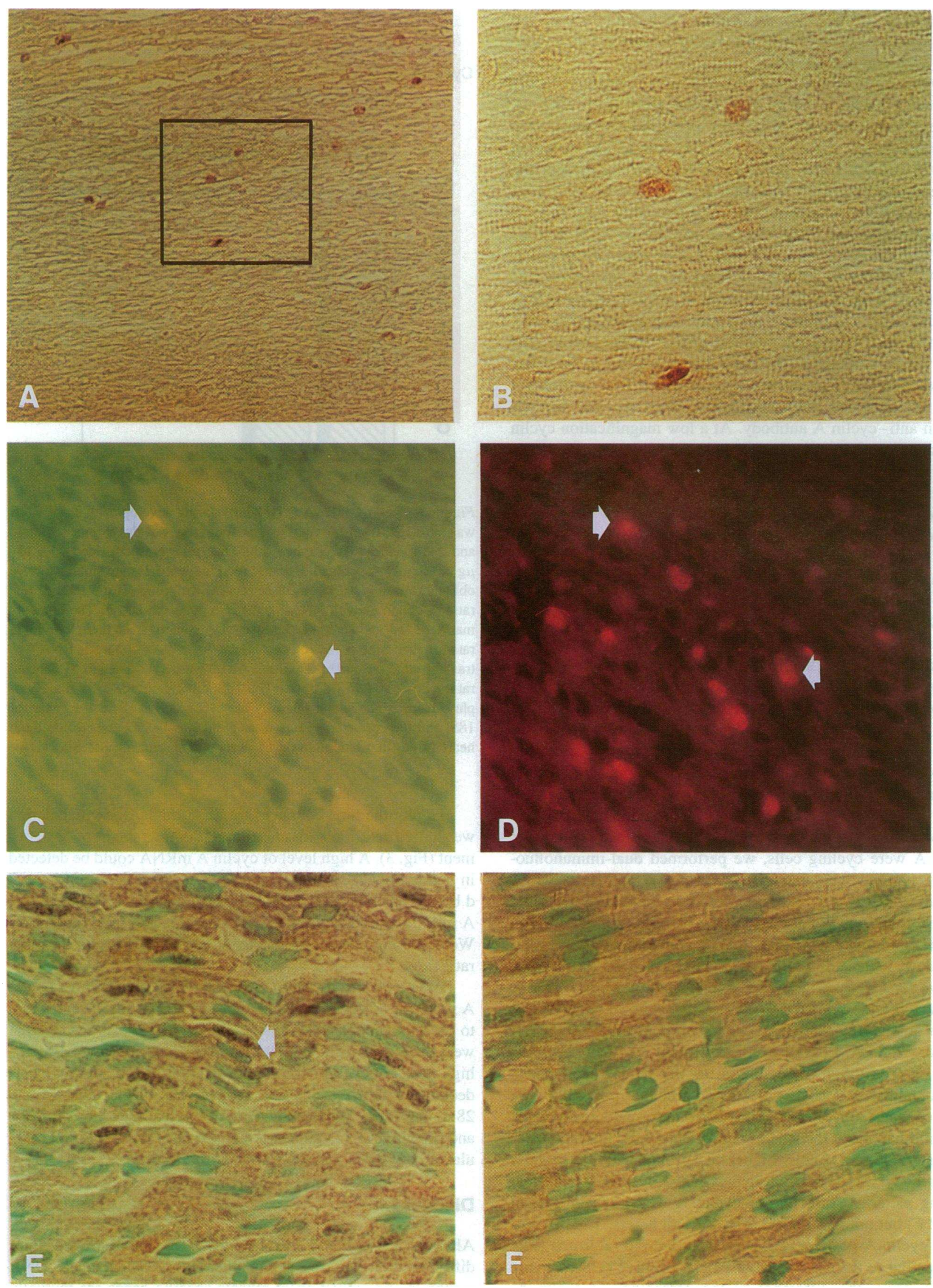
reported $(18,20-22,34)$. In contrast with lymphocytes and macrophages (20), cyclin D2 was not expressed in human umbilical vein endothelial cells.

Cyclin A, B (B1), C, D1, D2, D3, and E messages could be detected readily in RNA from human fetal hearts (Fig. 1). Although there were no significant differences between adult and fetal hearts in cyclin C, D1, D2, D3, and E mRNA levels, cyclin B mRNA levels decreased. Most interesting was the difference between fetal and adult hearts in the expression of cyclin A mRNA. Cyclin A mRNA was readily detectable in fetal hearts after the filters had been exposed to XAR film for $12 \mathrm{~h}$ (Fig. 1); however, even after $3 \mathrm{~d}$ of exposure cyclin A mRNA could not be detected in heart tissue from adults (data not shown). (The two sizes of cyclin A mRNA visible in Fig. 1 are due to the use of alternative polyadenylation signals (42).

Although we detected cyclin A mRNA in the human fetal heart, we were not sure which cell type expressed it. To determine whether cyclin A protein was present in fetal cardiomyocytes we incubated paraformaldehyde-fixed cryostat sections with an anti-cyclin $\mathrm{A}$ antibody. At a low magnification cyclin A immunoreactivity was detectable in the fetal heart (Fig. $2 \mathrm{~A}$ ), although only $4 \%$ of the cells expressed the protein. At high magnification cardiomyocytes were easily identified by their striated pattern and large nuclei (Fig. $2 B$ ). Fig. $2 B$ shows three representative cardiomyocytes immunoreactive for cyclin $A$. Also, cyclin A immunostaining was localized to the nuclear region of cardiomyocytes, consistent with previous reports that cyclin A and Cdk2 localize to nuclei of other cell types, particularly at sites of DNA replication $(43,44)$. Because desmin localizes to the $\mathrm{Z}$ bands of fetal and adult cardiomyocytes (45) it makes a good marker for them. We also performed dualimmunofluorescent studies with anti-desmin and anti-cyclin A antibodies and confirmed that the cells that stained positive for cyclin A were cardiomyocytes (data not shown). The specificity of the antisera was confirmed by incubation with irrelevant antibodies, such as anti-LHRH antibody, or normal goat serum. No immunostaining could be detected when tissue was incubated with these irrelevant antibodies (data not shown).

To confirm that the cardiomyocytes that stained positive for cyclin A were cycling cells, we performed dual-immunofluorescent staining with anti-human cyclin $A$ and anti-PCNA antibodies. PCNA has been used before as a marker for cycling cells, including cardiomyocytes (46-50). Fig. $2 C$ shows two cells from a human fetal heart stained with antibodies to cyclin A (yellow, indicated by arrows). These same cells also stained positive for PCNA (Fig. $2 D$, red, indicated by arrows). These results suggest that the cyclin A-positive cells were cycling. It is also noteworthy that more cells stained positive for PCNA than for cyclin A. Loss of cyclin A protein may have been the result of postmortem degradation, as the human fetal hearts were obtained $\sim 2 \mathrm{~h}$ after death. To test this possibility, we perfused anesthetized rats with $4 \%$ paraformaldehyde while alive and harvested their hearts immediately for immunohistochemistry. Despite slightly higher background activity (because the antibody was generated against human cyclin A), nuclear staining patterns distinctive of cyclin $A$ were seen in 2-d-old (Fig. $2 E$ ) but not in 14-d-old (Fig. $2 F$ ) rat hearts. The percentage of cyclin A-positive cells was 20 in 2-d-old rat hearts (Fig. $2 E$ ), similar to the percentage of PCNA-positive cells (data not shown). Thus, the difference in the percentage of cyclin Apositive cells in human and rats was more likely due to postmortem degradation of cyclin A protein.
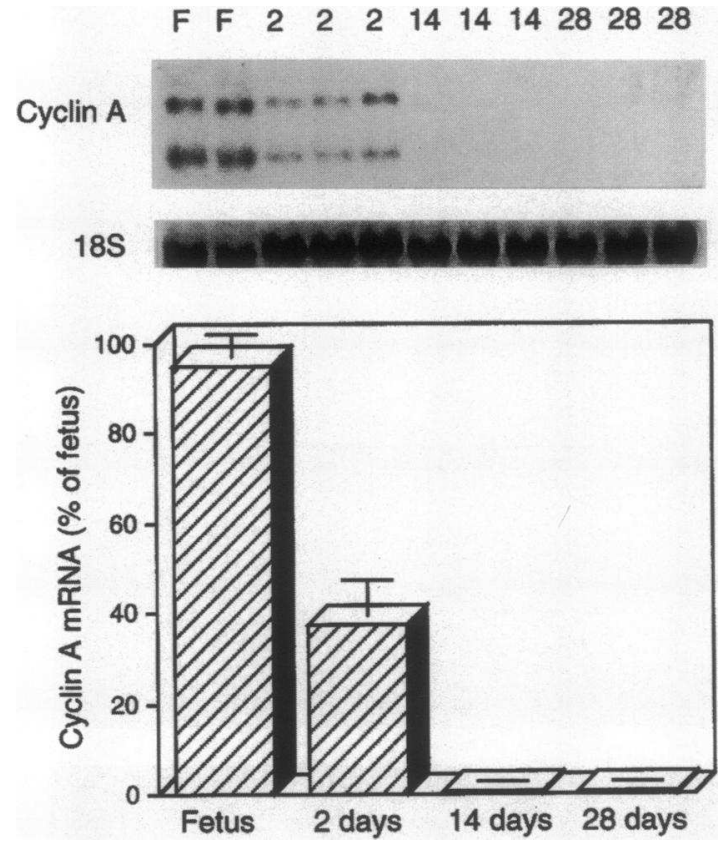

Figure 3. Cyclin A mRNA in rat hearts during development. Total RNA was extracted from rat ventricles at four stages of development (fetal and 2, 14, and 28 d). Northern blot analyses were performed with 15 $\mu \mathrm{g}$ of total RNA per lane. Because fetal rat ventricles are small we were obliged to pool tissue from three rats in two groups (for a total of 6 rats) to obtain enough RNA for the two lanes marked $F$. The lanes marked 2, 14, and 28 contained total RNA isolated from three individual rats for each time point, run separately. After electrophoresis RNA was transferred to nitrocellulose filters, which were hybridized to ${ }^{32} \mathrm{P}$-labeled rat cyclin $\mathrm{A}$ and $18 \mathrm{~S}$ probes. (The $18 \mathrm{~S}$ autoradiogram is from a PhosphorImager.) The signal intensity for cyclin $\mathrm{A}$ was divided by that for $18 \mathrm{~S}$, and the corrected values were plotted as a percentage of the fetal heart value (first lane marked $F$ ). Values represent means \pm SE.

To plot the time course of cyclin A mRNA downregulation we studied ventricular tissue from rats at four stages of development (Fig. 3). A high level of cyclin A mRNA could be detected in hearts obtained from rat fetuses $(18-19 \mathrm{~d}$ gestation or $\sim 2$ $\mathrm{d}$ before birth). However, in hearts from 2-d-old rats the cyclin A mRNA level decreased to $37 \%$ that in hearts from rat fetuses. We could not detect any cyclin A mRNA in 14- and 28-d-old rat hearts.

We performed Western blot analysis to confirm that cyclin A protein was downregulated after birth (Fig. 4). The antiserum to cyclin A recognized a 58-kD band in cycling HeLa cells that were used as a positive control $(38,39)$. Although we detected high levels of cyclin A protein in fetal rat hearts, protein levels declined within $2 \mathrm{~d}$ of birth. Protein was undetectable 14 and $28 \mathrm{~d}$ after birth. These coincident decreases in cyclin A mRNA and protein levels in rat hearts suggest that cyclin $A$ is downregulated between 2 and $14 \mathrm{~d}$ after birth.

\section{Discussion}

Although cardiac and skeletal muscle are both striated, their differentiation patterns are distinct. In skeletal muscle DNA synthesis and activation of muscle-specific genes are mutually exclusive $(5,51,52)$; in cardiac muscle proliferation and differentiation occur simultaneously (8). Thus, the molecular mecha- 


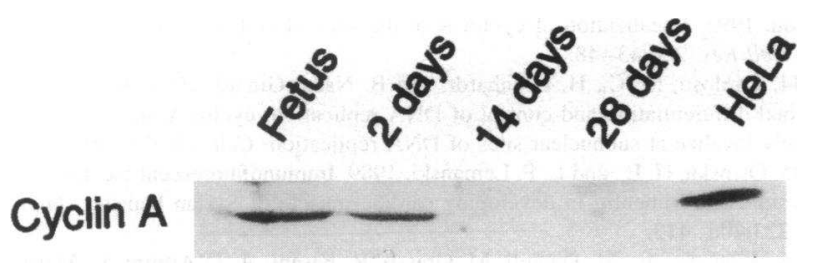

Figure 4. Cyclin A protein in rat hearts during development. Total protein extracts were obtained from fetal and neonatal rat ventricles. Protein from HeLa cells served as controls. Extracts were separated by sodium dodecylsulfate polyacrylamide gel electrophoresis according to standard protocols (36) and transferred to a polyvinylidene difluoride membrane. Cyclin A protein was detected with rabbit anti-human cyclin A antibody (1:5000 dilution).

nisms that control proliferation and terminal differentiation in these two striated cell types may be quite distinct $(5-7,53)$. Although several molecules have been implicated in the terminal differentiation of skeletal muscle cells $(5,51,52,54)$, very little is known about the molecular mechanisms regulating the terminal differentiation of cardiac muscle cells and their withdrawal from the cell cycle $(5,49,55)$.

Despite the importance of cyclins in regulating the progress of the mammalian cell cycle, there has been no report on cyclin gene expression in cardiomyocytes during terminal differentiation. In this report we have shown that the mRNA levels of the G1 cyclins (C, D1, D2, D3, and E) in fetal and adult hearts are essentially identical (Fig. 1). In contrast, cyclin B mRNA expression decreases markedly and cyclin A mRNA expression is suppressed in adult compared with fetal hearts (Figs. 1 and 3). It has been shown that by day 15 of postnatal rodent development essentially all cardiomyocytes have exited the cell cycle $(8,56)$. Our observations about the time course of cyclin A mRNA downregulation (Fig. 3) correlate well with the withdrawal of cardiomyocytes from the cycle. Moreover, cyclin A is required for the $S$ and $G 2 / M$ phases of the cell cycle $(16,17$, 57). Inhibition of cyclin A synthesis or activity - by microinjection of plasmids encoding antisense cyclin A cDNA or by anticyclin A antibodies - inhibits DNA synthesis and mitosis in fibroblasts $(16,17)$. Therefore the complete disappearance of cyclin A in adult hearts may have an important role in the withdrawal of adult cardiomyocytes from the cell cycle.

It is interesting to note that levels of the G1 cyclins (D and E) in adult hearts remained elevated whereas those for cyclin A declined dramatically. Although we cannot exclude the possibility that noncardiomyocytes contributed to these high G1 cyclin levels, this situation is strikingly similar to that seen in senescent human fibroblasts (58), in which cyclin $A$ was undetectable and cyclins $D$ and $E$ were expressed at high levels. In this regard terminal differentiation and senescence may share regulatory pathways controlling cell cycle progression.

It has been reported that endogenous cAMP concentrations increase progressively in rat hearts during late fetal and early neonatal development (59). Furthermore, exogenous cAMP can cause premature withdrawal of cardiomyocytes from the cell cycle (59). The human cyclin A promoter has recently been cloned and a cAMP-responsive element has been identified 73 bp $5^{\prime}$ to the major transcription start site $(42,60)$. It will be interesting to test whether cAMP downregulates the expression of the cyclin A gene in cardiomyocytes.

To our knowledge this is the first report that cyclin A disap- pears in adult cardiomyocytes. Elucidation of the molecular mechanisms regulating downregulation of cyclin A gene expression in adult cardiomyocytes will provide further insight into their permanent withdrawal from the cell cycle. Only when the mechanisms regulating this withdrawal are fully understood can we design strategies for regenerating damaged cardiac tissue.

\section{Acknowledgments}

We extend our gratitude to Edgar Haber for his continued enthusiasm and support of our work. We thank Dr. Haber for his helpful suggestions and critical review of the manuscript and Thomas McVarish and Photina Ree for their editorial assistance.

This work was supported by a grant from the Bristol-Myers Squibb Pharmaceutical Research Institute. Dr. Lee was supported by a Clinician Scientist Award and a Grant-in-Aid from the American Heart Association, with funds contributed in part by the AHA, Massachusetts Affiliate.

\section{References}

1. Beinlich, C. J., and H. E. Morgan. 1993. Control of growth in neonatal pig hearts. Mol. Cell. Biochem. 119:3-9.

2. Casscells, W., E. Speir, I. Sasse, M. Klagsbrun, P. Allen, M. Lee, B. Calvo, M. Chiba, L. Haggroth, J. Folkman, and S. E. Epstein. 1990. Isolation, characterization, and localization of heparin-binding growth factors in the heart. J. Clin. Invest. 85:433-441.

3. Speir, E., V. Tanner, A. M. Gonzalez, J. Farris, A. Baird, and W. Casscells. 1992. Acidic and basic fibroblast growth factors in adult rat heart myocytes. Localization, regulation in culture, and effects on DNA synthesis. Circ. Res. 71:251-259.

4. Knowlton, K. U., M. C. Michel, M. Itani, H. E. Shubeita, K. Ishihara, J. H. Brown, and K. R. Chien. 1993. The alpha 1A-adrenergic receptor subtype mediates biochemical, molecular, and morphologic features of cultured myocardial cell hypertrophy. J. Biol. Chem. 268:15374-15380.

5. Claycomb, W. C. 1992. Control of cardiac muscle cell division. Trends Cardiovasc. Med. 2:231-236.

6. Parker, T. G., and M. D. Schneider. 1991. Growth factors, proto-oncogenes, and plasticity of the cardiac phenotype. Annu. Rev. Physiol. 53:179-200.

7. Simpson, P. C. 1989. Proto-oncogenes and cardiac hypertrophy. Annu. Rev. Physiol. 51:189-202.

8. Rumyantsev, P. P. 1977. Interrelations of the proliferation and differentiation processes during cardiac myogenesis and regeneration. Int. Rev. Cytol. 51:186-273.

9. Sherr, C. J. 1993. Mammalian $\mathrm{G}_{1}$ cyclins. Cell. 73:1059-1065.

10. Hunter, T., and J. Pines. 1991. Cyclins and cancer. Cell. 66:1071-1074.

11. Hunter, T. 1993. Braking the cycle. Cell. 75:839-841.

12. Krek, W., and E. A. Nigg. 1989. Structure and developmental expression of the chicken CDC2 kinase. EMBO (Eur. Mol. Biol. Organ.) J. 8:3071-3078.

13. Lee, M. G., and P. Nurse. 1987. Complementation used to clone a human homologue of the fission yeast cell cycle control gene cdc2. Nature (Lond.). 327:31-35.

14. Tsai, L. H., E. Harlow, and M. Meyerson. 1991. Isolation of the human cdk2 gene that encodes the cyclin A- and adenovirus E1A-associated p33 kinase. Nature (Lond.). 353: 174-177.

15. Heichman, K. A., and J. M. Roberts. 1994. Rules to replicate by. Cell. 79:557-562.

16. Pagano, M., R. Pepperkok, F. Verde, W. Ansorge, and G. Draetta. 1992. Cyclin $\mathrm{A}$ is required at two points in the human cell cycle. EMBO (Eur. Mol. Biol. Organ.) J. 11:961-971.

17. Girard, F., U. Strausfeld, A. Fernandez, and N. J. Lamb. 1991. Cyclin A is required for the onset of DNA replication in mammalian fibroblasts. Cell. 67:1169-1179.

18. Pines, J., and T. Hunter. 1989. Isolation of a human cyclin cDNA: evidence for cyclin mRNA and protein regulation in the cell cycle and for interaction with p34 ${ }^{\text {cdc2 }}$. Cell. 58:833-846.

19. Xiong, Y., T. Connolly, B. Futcher, and D. Beach. 1991. Human D-type cyclin. Cell. 65:691-699.

20. Matsushime, H., M. F. Roussel, R. A. Ashmun, and C. J. Sherr. 1991. Colony-stimulating factor 1 regulates novel cyclins during the $\mathrm{G} 1$ phase of the cell cycle. Cell. 65:701-713.

21. Lew, D. J., V. Dulic, and S. I. Reed. 1991. Isolation of three novel human cyclins by rescue of G1 cyclin (Cln) function in yeast. Cell. 66: 1197-1206.

22. Koff, A., F. Cross, A. Fisher, J. Schumacher, K. Leguellec, M. Philippe, and J. M. Roberts. 1991. Human cyclin E, a new cyclin that interacts with two members of the CDC2 gene family. Cell. 66:1217-1228. 
23. Hunter, T., and J. Pines. 1994. Cyclins and cancer II: cyclin D and CDK inhibitors come to age. Cell. 79:573-582.

24. Sherr, C. J. 1994. G1 phase progression: cycling on cue. Cell. 79:551 555.

25. Peter, M., and I. Herskowitz. 1994. Joining the complex: cyclin-dependant kinase inhibitory proteins and the cell cycle. Cell. 79:181-184.

26. Polyak, K., J. Kato, M. J. Solomon, C. J. Sherr, J. Massague, J. M. Roberts, and A. Koff. 1994. p27 $7^{\text {Kipl }}$, a cyclin-Cdk inhibitor, links transforming growth factor- $\beta$ and contact inhibition to cell cycle arrest. Genes \& Dev. 8:9-22.

27. Polyak, K., M. H. Lee, H. Erdjument-Bromage, A. Koff, J. M. Roberts, P. Tempst, and J. Massague. 1994. Cloning of p27 $7^{k p l}$, a cyclin-dependent kinase inhibitor and a potential mediator of extracellular antimitogenic signals. Cell. 78:59-66.

28. Toyoshima, H., and T. Hunter. 1994. p27, a novel inhibitor of G1 cyclinCdk protein kinase activity, is related to p21. Cell. 78:67-74.

29. Serrano, M., G. J. Hannon, and D. Beach. 1993. A new regulatory motif in cell-cycle control causing specific inhibition of cyclin D/CDK4. Nature (Lond.). 366:704-707.

30. El-Deiry, W. S., T. Tokino, V. E. Velculescu, D. B. Levy, R. Parsons, J. M. Trent, D. Lin, W. E. Mercer, K. W. Kinzler, and B. Vogelstein. 1993. WAF1, a potential mediator of p53 tumor suppression. Cell. 75:817-825.

31. Harper, J. W., G. R. Adami, N. Wei, K. Keyomarsi, and S. J. Elledge. 1993. The p21 Cdk-interacting protein Cip1 is a potent inhibitor of G1 cyclindependent kinases. Cell. 75:805-816.

32. Lee, M.-E., D. H. Temizer, J. A. Clifford, and T. Quertermous. 1991. Cloning of the GATA-binding protein that regulates endothelin-1 gene expression in endothelial cells. J. Biol. Chem. 266:16188-16192.

33. Yoshizumi, M., S. Kourembanas, D. H. Temizer, R. P. Cambria, T. Quertermous, and M.-E. Lee. 1992. Tumor necrosis factor increases transcription of the heparin-binding epidermal growth factor-like growth factor gene in vascular endothelial cells. J. Biol. Chem. 267:9467-9469.

34. Wang, J., X. Chenivesse, B. Henglein, and C. Bréchot. 1990. Hepatitis B virus integration in a cyclin A gene in a hepatocellular carcinoma. Nature (Lond.). 343:555-557.

35. Perrella, M. A., M. Yoshizumi, Z. Fen, J. C. Tsai, C. M. Hsieh, S. Kourembanas, and M.-E. Lee. 1994. Transforming growth factor- $\beta 1$, but not dexamethasone, down-regulates nitric-oxide synthase mRNA after its induction by interleukin-1 $\beta$ in rat smooth muscle cells. J. Biol. Chem. 269:14595-14600.

36. Ausubel, F. M., R. Brent, R. E. Kingston, D. D. Moore, J. G. Seidman, J. A. Smith, and K. Struhl, editors. 1993. Current Protocols in Molecular Biology. Greene Publishing Associates and John Wiley \& Sons, New York.

37. Laemmli, U. K. 1970. Cleavage of structural proteins during the assembly of the head of bacteriophage T4. Nature (Lond.). 227:680-685.

38. Meikrantz, W., S. Gisselbrecht, S. W. Tam, and R. Schlegel. 1994. Activation of cyclin A-dependent protein kinases during apoptosis. Proc. Natl. Acad. Sci. USA. 91:3754-3758.

39. Oshima, J., K. E. Steinmann, J. Campisi, and R. Schlegel. 1993. Modulation of cell growth, p34 ${ }^{\text {cdc2 }}$ and cyclin A levels by SV-40 large T antigen. Oncogene. 8:2987-2993.

40. Lee, W. S., M. S. Smith, and G. E. Hoffman. 1990. Leutenizing hormonereleasing hormone neurons express Fos protein during the proestrous surge of leutenizing hormone. Proc. Natl. Acad. Sci. USA. 87:5163-5167.

41. Kanai, Y., M. G. Stelzner, W. S. Lee, R. G. Wells, D. Brown, and M. A. Hediger. 1992. Expression of mRNA (D2) encoding a protein involved in amino acid transport in S3 proximal tubule. Am. J. Physiol. F1087-F1092.

42. Henglein, B., X. Chenivesse, J. Wanf, D. Eick, and C. Bréchot. 1994. Structure and cell cycle-regulated transcription of the human cyclin A gene. Proc. Natl. Acad. Sci. USA. 91:5490-5494.

43. Sobczak-Thepot, J., F. Harper, Y. Florentin, F. Zindy, C. Brechot, and E.
Puvion. 1993. Localization of cyclin A at the sites of cellular DNA replication. Exp. Cell Res. 206:43-48.

44. Cardoso, M. C., H. Leonhardt, and B. Nadal-Ginard. 1993. Reversal of terminal differentiation and control of DNA replication: cyclin A and cdk2 specifically localize at subnuclear sites of DNA replication. Cell. 74:979-992.

45. Osinska, H. E., and L. F. Lemanski. 1989. Immunofluorescent localization of desmin and vimentin in developing cardiac muscle of Syrian hamster. Anat. Rec. 223:406-413.

46. Arbustini, E., M. Diegoli, M. Grasso, R. Fasani, A. D'Armini, L. Martinelli, C. Goggi, C. Campana, A. Gavazzi, and M. Vigano. 1993. Expression of proliferating cell markers in normal and diseased human hearts. Am. J. Cardiol. 72:608-614.

47. Mathews, M. B., R. M. Bernstein, B. R. Franza, Jr., and J. I. Garrels. 1984. Identity of the proliferating cell nuclear antigen and cyclin. Nature (Lond.). 309:374-376.

48. Hall, P. A., D. A. Levison, A. L. Woods, C. C.-W. Yu, D. B. Kellock, J. A. Watkins, D. M. Barnes, C. E. Gillett, R. Camplejohn, R. Dover, N. H. Wasseem, and D. P. Lane. 1990. Proliferating cell nuclear antigen (PCNA) immunolocalization in paraffin sections: an index of cell proliferation with evidence of deregulated expression in some neoplasms. J. Pathol. 162:285-294.

49. Marino, T. A., S. Haldar, E. C. Williamson, K. Beaverson, R. A. Walter, D. R. Marino, C. Beatty, and K. E. Lipson. 1991. Proliferating cell nuclear antigen in developing and adult rat cardiac muscle cells. Circ. Res. 69:1353-1360.

50. Reiss, K., L. G. Meggs, P. Li, G. Olivetti, J. M. Capasso, and P. Anversa. 1994. Upregulation of $I_{\text {GF }}, I_{1}$ IF $_{1}$-receptor, and late growth related genes in ventricular myocytes acutely after infarction in rats. J. Cell. Physiol. 158:160-168.

51. Ueno, H., M. B. Perryman, R. Roberts, and M. D. Schneider. 1988 Differentiation of cardiac myocytes after mitogen withdrawal exhibits three sequential states of the ventricular growth response. J. Cell Biol. 107:1911-1918.

52. Nguyen, H. T., R. M. Medford, and B. Nadal-Ginard. 1983. Reversibility of muscle differentiation in the absence of commitment: analysis of a myogenic cell line temperature-sensitive for commitment. Cell. 34:281-293.

53. Perrella, M. A., T. Măki, S. Prasad, D. Pimental, K. Singh, N. Takahashi, M. Yoshizumi, A. Alali, S. Higashiyama, R. A. Kelly, M.-E. Lee, and T. W. Smith. 1994. Regulation of heparin-binding epidermal growth factor-like growth factor (HB-EGF) mRNA levels by hypertrophic stimuli in neonatal and adult rat cardiac myocytes. J. Biol. Chem. 269:14595-14600.

54. Jahn, L., J. Sadoshima, and S. Izumo. 1994. Cyclins and cyclin-dependent kinases are differentially regulated during terminal differentiation of $\mathrm{C} 2 \mathrm{C} 12$ muscle cells. Exp. Cell Res. 212:297-307.

55. Schneider, M. D., P. A. Payne, H. Ueno, M. B. Perryman, and R. Roberts. 1986. Dissociated expression of c-myc and a fos-related competence gene during cardiac myogenesis. Mol. Cell. Biol. 6:4140-4143.

56. Gruver, C. L., S. E. George, and A. R. Means. 1992. Cardiomyocyte growth regulation by $\mathrm{Ca}^{2+}$-calmodulin. Trends Cardiovasc. Med. 2:226-231.

57. Guadagno, T. M., M. Ohtsubo, J. M. Roberts, and R. K. Assoian. 1993. A link between cyclin A expression and adhesion-dependent cell cycle progression. Science (Lond.). 262:1572-1575.

58. Dulic, V., L. F. Drullinger, E. Lees, S. I. Reed, and G. H. Stein. 1993. Altered regulation of $G_{1}$ cyclins in senescent human diploid fibroblasts: accumulation of inactive cyclin E-Cdk2 and cyclin D1-Cdk2 complexes. Proc. Natl. Acad. Sci. USA. 90:11034-11038.

59. Claycomb, W. C. 1976. Biochemical aspects of cardiac muscle differentiation: possible control of deoxyribonucleotide acid synthesis and cell differentiation by adrenergic innervation and cyclic AMP. J. Biol. Chem. 251:6082-6089.

60. Yamamoto, M., M. Yoshida, K. Ono, T. Fujita, N. Ohtani-Fujita, T. Sakai, and T. Nikaido. 1994. Effect of tumor suppressers on cell cycle-regulatory genes: RB suppresses p34 ${ }^{\text {odc2 }}$ expression and normal p53 suppresses cyclin A expression. Exp. Cell Res. 210:94-101. 